\title{
Comparing Institution Nitrogen Footprints: Metrics for Assessing and Tracking Environmental Impact
}

\author{
Elizabeth A. Castner, ${ }^{1}$ Allison M. Leach, ${ }^{2}$ Jana E. Compton, ${ }^{3}$ \\ James N. Galloway, and Jennifer Andrews ${ }^{4}$
}

\section{Abstract}

When multiple institutions with strong sustainability initiatives use a new environmental impact assessment tool, there is an impulse to compare. The first seven institutions to calculate nitrogen footprints using the Nitrogen Footprint Tool have worked collaboratively to improve calculation methods, share resources, and suggest methods for reducing their footprints. This article compares those seven institutions' results to reveal the common and unique drivers of institution nitrogen footprints. The footprints were compared by scope and sector, and the results were normalized by multiple factors (e.g., population, amount of food served). The comparisons found many consistencies across the footprints, including the large contribution of food. The comparisons identified metrics that could be used to track progress, such as an overall indicator for the nitrogen sustainability of food purchases. The comparisons also pointed to differences in system bounds of the calculations, which are important to standardize when comparing across institutions. The footprints were influenced by factors both within and outside of the institutions' ability to control, such as size, location, population, and campus use. However, these comparisons also point to a pathway forward for standardizing nitrogen footprint tool calculations, identifying metrics that can be used to track progress, and determining a sustainable institution nitrogen footprint.

Keywords: energy; environmental impact; food; indicator; metric; nitrogen footprint; sustainability

\section{Introduction}

The Nitrogen Footprint Tool (NFT) for institutions quantifies the amount of reactive nitrogen lost to the environment as a result of an institution's consumption of food, energy, and other resources. The tool calculates an absolute value in the form of a nitrogen $(\mathrm{N})$ footprint and has projection and reduction scenario calculation capabilities. A stand-alone $\mathrm{N}$ footprint result can help institutions understand their overall environmental impact by showing which activities or sectors have the greatest influence on the footprint. The tool can also suggest methods for reducing the $\mathrm{N}$ footprint and can be used to track the footprint over time.

Additional value from the results of the $\mathrm{N}$ footprint calculation is revealed when footprints of different institutions are compared. This ar- ticle compares the results of the first seven institutions to complete $\mathrm{N}$ footprint calculations: Brown University, Colorado State University (CSU), Dickinson College, Eastern Mennonite University (EMU), Marine Biological Laboratory (MBL), University of New Hampshire (UNH), and University of Virginia (UVA). The $\mathrm{N}$ footprint results for these institutions are presented and discussed in Castner et al. in this issue. ${ }^{1}$

'Department of Environmental Sciences, University of Virginia, Charlottesville, Virginia.

2Department of Natural Resources \& the Environment, The Sustainability Institute, University of New Hampshire, Durham, New Hampshire.

${ }^{3}$ Western Ecology Division, U.S. Environmental Protection Agency, Corvallis, Oregon.

${ }^{4}$ The Sustainability Institute, University of New Hampshire, Durham, New Hampshire.

(c) Elizabeth A. Castner et al., 2017; Published by Mary Ann Liebert, Inc. This Open Access article is distributed under the terms of the Creative Commons Attribution Noncommercial License (http://creativecommons.org/licenses/by-nc/4.0), which permits any noncommercial use, distribution, and reproduction in any medium, provided the original author(s) and the source are credited. 
Institution footprints have been compared for a different type of footprint: the carbon footprint. The Campus Carbon Calculator ${ }^{\mathrm{rm}}$, which was developed in partnership with Clean Air-Cool Planet and is now managed by the University of New Hampshire, is the carbon footprint tool used by over 90 percent of colleges and universities in the United States that track their carbon footprint. Because of its focus on energy, the comparisons made among institutions are normalized based on the population (full-time equivalents) and gross square footage. ${ }^{2}$ Comparisons have identified key drivers of carbon footprints to be institution size, density, location, age profile, and capital investment portfolio. These findings can help inform the types of comparisons completed for other footprints, although the focus on energy may necessitate other ways to normalize sectors outside of energy.

This article compares the nitrogen footprint results from seven institutions based on metrics of population, physical size, and food purchasing to assess what factors control the magnitude of their $\mathrm{N}$ footprints. Institution population and physical size are metrics commonly used to normalize greenhouse gas inventories and will be applied to the nitrogen footprint. Novel food purchasing factors are used to explore which are most relevant to institution $\mathrm{N}$ footprints. Four new factors for comparing food nitrogen footprints are presented: percent animal product purchases, average percent protein content, average institution virtual nitrogen factor, and food $\mathrm{N}$ footprint per kilogram of food. The merits and drawbacks of each are discussed. Assessing several institution $\mathrm{N}$ footprints together with comparison metrics gives a holistic understanding of how university communities contribute to nitrogen pollution and how they might minimize their impact.

\section{Methods}

\section{Overall Nitrogen Footprint Comparisons}

The $\mathrm{N}$ footprint calculations resulting from the work done at each institution were collectively assessed using common comparison metrics. These comparisons aim to identify trends, drivers, and outliers. The total institution $\mathrm{N}$ footprints were first compared by scopes. The average percent contribution for each sector was calculated. The total institution $\mathrm{N}$ footprints were normalized to the full-time equivalent population, which takes into account how often different populations (e.g., students, faculty, staff) are on campus. The comparisons and normalizations performed in this study are listed in Table 1. Institution carbon footprints are commonly compared by the full-time equivalent population metric standardized by the Association for the Advancement of Sustainability in Higher Education (AASHE) STARS, a comprehensive sustainability rating system used by upward of 1,000 colleges and universities, and the Campus Carbon Calculator $^{\text {mit }} \cdot{ }^{2}$

One way that the sectors of a footprint can be grouped is by scopes. ${ }^{3}$ Scopes are used to describe where reactive nitrogen $(\mathrm{Nr})$ is released to the environment and how directly the entity being assessed is involved in the decisions driving the emissions. Scope 1 includes on-site utilities, institution transportation, research animal carcasses and waste, and on-campus fertilizer; scope 2 includes off-site utilities (purchased electricity); and scope 3 covers food production, food consumption (i.e., wastewater), and commuting. Food production for research animals is also included in scope 3 . Based on the scopes used for greenhouse gas emissions, these scopes are useful for identifying the components of the $\mathrm{N}$ footprint that an institution has the ability to change, as well as the geographical source of reactive nitrogen emissions.

Scope 1 emissions are on-site and directly controlled by institution consumption. Scope 2 emissions are not on-site, and are indirectly con-

\begin{tabular}{|c|c|c|}
\hline & Comparisons & Normalizations \\
\hline Total N footprint & $\begin{array}{l}\cdot \text { Total N footprint } \\
\text { - By sector } \\
\text { - By scope }\end{array}$ & $\begin{array}{l}\text { - Per capita } \\
\text { - Per gross square footage }\end{array}$ \\
\hline Food & $\begin{array}{l}\text { - Food } \mathrm{N} \text { footprint } \\
\text { - By food category }\end{array}$ & $\begin{array}{l}\text { - Per } \mathrm{kg} \text { food } \\
\text { - Institution virtual } \mathrm{N} \text { factor } \\
\text { - Per meal served } \\
\text { - \% animal purchases } \\
\text { - \% protein content }\end{array}$ \\
\hline Utilities & - Utilities $\mathrm{N}$ footprint & - Per gross square footage \\
\hline Transportation & - Transportation $\mathrm{N}$ footprint & - Per capita \\
\hline
\end{tabular}


trolled by institution consumption. Scope 3 emissions are considered supply-chain emissions and are also off-site and indirectly controlled by institution consumption, but cannot necessarily be controlled by topdown consumption changes, since many of the consumption choices at institutions, especially food, are driven by individual choices. ${ }^{3} \mathrm{Ni}$ trogen emissions can be classified as upstream (pre-consumption) and downstream (post-consumption).

\section{Food Nitrogen Footprint Comparisons}

Food N footprints should not be normalized by population because the portion of the institution population served by on-site dining differs across institutions. A linear regression between the number of meals served and the food production $\mathrm{N}$ footprint was performed to determine if a relationship exists between the two measures. The percent contribution of each food category to the total food production $\mathrm{N}$ footprint was also compared.

Four comparison metrics are presented to help institutions track and improve the sustainability of their dining purchases. These metrics include percent of purchases that were animal products, average percent protein of food purchased, average institution virtual nitrogen factors, and the $\mathrm{N}$ footprint per unit of food purchase weight (Table 1).

\section{Energy Nitrogen Footprint Comparisons}

The $\mathrm{N}$ footprints of utilities were normalized and compared by gross square footage (GSF), which is a measure of campus building area. A linear regression of an institution's gross square footage and $\mathrm{N}$ footprint was performed to determine if a relationship exists. Transportation $\mathrm{N}$ footprints were compared on a per capita basis, again, using the full-time equivalent institution population (Table 1).

\section{Results}

\section{Overall Nitrogen Footprint Comparisons}

The institutions included in this study vary in size (both population and gross square footage of campus) and mission (a research institution, small liberal arts colleges, and large research universities). ${ }^{1}$ Accordingly, there is a broad distribution of $\mathrm{N}$ footprint results-from 7.5 metric tons nitrogen (MT N) at Marine Biological Laboratory (MBL) to 444 metric tons nitrogen (MT N) at the University of Virginia (Figure 1).

An analysis of institution $\mathrm{N}$ footprints broken up by sector provides useful information about which university activities are the largest contributors. Food production was consistently the largest contributor to all institution $\mathrm{N}$ footprints, making up 50 percent (SD 18\%) of the total $\mathrm{N}$ footprint on average (Figure 2). The utilities sector was the second largest (33\%; standard deviation 17\%); all other sectors contributed less than 10 percent of the total $\mathrm{N}$ footprint. The average total $\mathrm{N}$ footprint for these seven institutions is 163 metric tons nitrogen (SD 157 MT N).

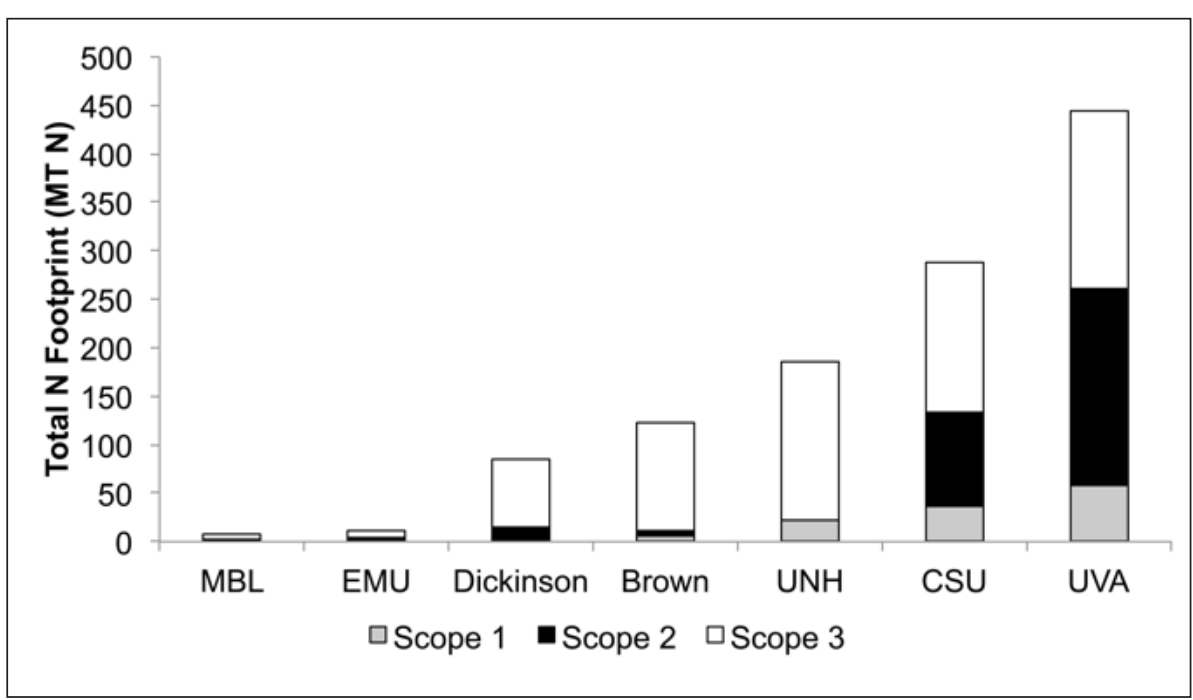

Figure 1.Total N footprint results categories divided into three scopes; results for the seven institutions

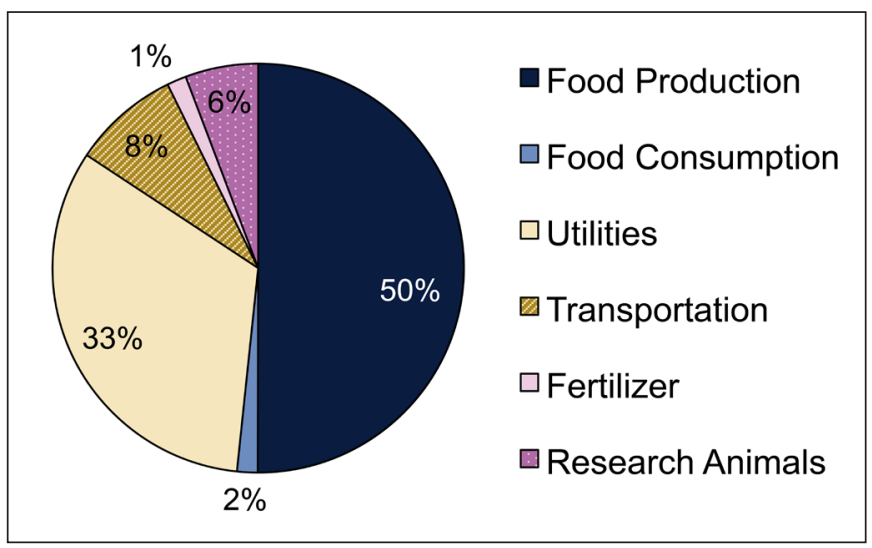

Figure 2. The average percentage for each sector (food production, food consumption, utilities, transportation, fertilizer, and research animals) of institution $\mathrm{N}$ footprint totals for the seven institutions 


Table 2. The Institution Population and the Campus Size in Gross Square
Footage of Building Space
\begin{tabular}{|l|c|c|}
\hline & $\begin{array}{c}\text { Institution Population (normalized } \\
\text { number of campus users) }\end{array}$ & $\begin{array}{c}\text { Campus Size (Building Space } \\
\text { Gross Square Footage) }\end{array}$ \\
Brown & 7,900 & $6,400,000$ \\
CSU & 31,000 & $10,600,000$ \\
Dickinson & 3,100 & $1,962,000$ \\
EMU & 1,600 & 634,000 \\
MBL & 330 & 394,000 \\
UNH & 16,500 & $6,100,000$ \\
UVA & 36,000 & $17,200,000$ \\
\hline
\end{tabular}

Looking at $\mathrm{N}$ footprints broken out by scopes instead of sectors provides insight into both where emissions occur (on- or off-site) and the degree of responsibility of the institution. Scopes 2 and 3, or off-site emissions, are dominant for all footprints because they encompass the food production and purchased utilities sectors, which are the largest sources of reactive nitrogen emissions resulting from institutional activities (Figure 1). Scope 1 emissions (on-site utilities, transportation provided by the institution, on-site fertilizer application, and research animal waste), which occur on campus and are most directly tied to institution activities, are smaller, indicating that most of the reactive nitrogen emissions in an institution footprint occur elsewhere. Given the differences in institution sizes (Table 2), the $\mathrm{N}$ footprints were normalized by gross square footage and institution population to assess what factors drive an institution's $\mathrm{N}$ footprint.

When the footprints are compared by institution population, they range from 7 kilograms of nitrogen per person per year (EMU) to $27 \mathrm{ki}$ lograms of nitrogen per person per year (Dickinson) (Figure 3). The average $\mathrm{N}$ footprint for an individual in the United States is 39 kilograms tion activities, such as laboratories. each. Results are shown for the seven institutions.

\section{Food Nitrogen Footprint Comparisons}

While normalizing by institution population can be useful for the total $\mathrm{N}$ footprint, the comparison can be misleading because of how institutions differ in the services provided within their system bounds. An alternative way to normalize the food $\mathrm{N}$ footprint is by the number of meals served. A linear regression between food production $\mathrm{N}$ footprints and number of meals served was performed to determine if a metric like the number of meals served at an institution could predict the $\mathrm{N}$ footprint for other institutions. While the correlation $\left(\mathrm{R}^{2}=0.71\right.$, $p<0.01$ ) between food production $\mathrm{N}$ footprint and the number of meals served is significant, it is not the most reliable metric. (See Figure S1, which may be found online at www.liebertpub.com/sus.)

As more institutions calculate their food $\mathrm{N}$ footprints, this may become possible. The number of meals served does not always accurately represent the amount of food served

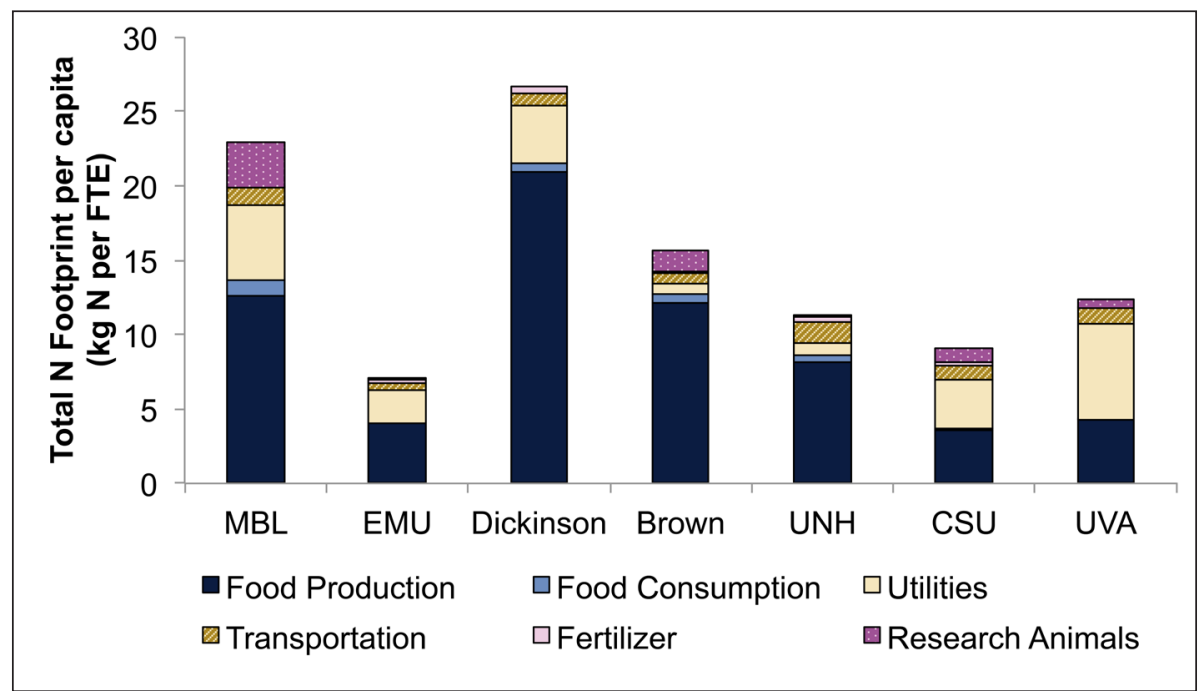

Figure 3. Institution N footprint results per FTE (full time equivalent) population and scopes for 
through university dining services because of how meals are counted. For the purposes of data collection, most schools provided the number of meal card swipes, which do not always represent a meal because student meal plans allow students to get any amount of food for one swipe. Meal card swipes also do not typically include the food served in retail locations, which count sales in terms of dollar amount rather than number of meals. Therefore, comparison of food $\mathrm{N}$ footprints based on number of meals served could be skewed by the amount of food consumed per meal swipe and the amount of food sold outside of dining halls in retail locations.

Four alternative food comparison metrics can, together, give a fuller picture of how institution $\mathrm{N}$ footprints compare: percent of purchases that are animal products, average protein content (\%), average institution virtual nitrogen factor, and virtual nitrogen by purchased weight (Table 3). Animal product percent of purchases represents the amount of food purchased, by weight, that is categorized as meat, fish, dairy, and eggs. Meat and animal products generally have higher $\mathrm{N}$ footprints than crops. Animal product purchases averaged 34 percent of total purchases by weight, with a range from 14 percent to 49 percent. The average protein content takes into account the protein contained in all foods. Animal-based products tend to drive up the average protein content, although nuts and legumes are non-animal products that have higher protein content. The average protein content of purchases was 8 percent, ranging from 4 percent to 11 percent. The institution virtual nitrogen factor (VNF) metric shows the average VNF for all food pur-

\begin{tabular}{|c|c|c|c|c|c|c|}
\hline Institution & $\begin{array}{l}\text { Total Food } \\
\text { Purchases }\end{array}$ & $\begin{array}{l}\text { Animal } \\
\text { Product } \\
\text { Purchases }\end{array}$ & $\begin{array}{l}\text { Average } \\
\text { Protein } \\
\text { Content of } \\
\text { Food } \\
\text { Purchases }\end{array}$ & $\begin{array}{l}\text { Institution } \\
\text { VNF }\end{array}$ & $\begin{array}{l}\text { Virtual N } \\
\text { per Food } \\
\text { Weight }\end{array}$ & $\begin{array}{l}\text { Sewage } \\
\text { Treatment } \\
\text { Nr Removal } \\
\text { Factor }\end{array}$ \\
\hline & $\begin{array}{l}\text { Metric } \\
\text { tons }\end{array}$ & $\begin{array}{l}\% \text { of Total } \\
\text { Purchases } \\
\text { by weight }\end{array}$ & $\%$ Protein & $\begin{array}{l}\text { Total Virtual } \\
\mathrm{N} / \text { Total N } \\
\text { in Food } \\
\text { Purchases }\end{array}$ & $\begin{array}{l}\mathrm{kg} \text { virtual } \\
\mathrm{N} / \mathrm{kg} \text { food } \\
\text { purchases }\end{array}$ & $\begin{array}{l}\% \mathrm{Nr} \\
\text { removed }\end{array}$ \\
\hline Brown & 2,700 & $27 \%$ & $7 \%$ & 3.2 & 35 & $79 \%$ \\
\hline CSU & 2,100 & $27 \%$ & $9 \%$ & 3.8 & 52 & $42 \%$ \\
\hline Dickinson & 1,100 & $45 \%$ & $10 \%$ & 3.9 & 62 & $88 \%$ \\
\hline EMU & 110 & $49 \%$ & $10 \%$ & 3.9 & 63 & $96 \%$ \\
\hline $\mathrm{MBL}$ & 130 & $14 \%$ & $4 \%$ & 4.2 & 31 & $50 \%$ \\
\hline UNH & 2,000 & $44 \%$ & $11 \%$ & 3.7 & 66 & $74 \%$ \\
\hline UVA & 3,300 & $34 \%$ & $8 \%$ & 3.6 & 46 & $94 \%$ \\
\hline $\begin{array}{l}\text { Weighted } \\
\text { average }\end{array}$ & $\mathrm{N} / \mathrm{A}$ & $34 \%$ & $8 \%$ & 3.6 & 50 & $\mathrm{~N} / \mathrm{A}$ \\
\hline
\end{tabular}

N/A, not applicable.

chases based on the calculated total amount of virtual nitrogen divided by the nitrogen contained in food.

The average institution VNF was 3.6. A higher institution VNF does not necessarily mean a higher $\mathrm{N}$ footprint because some food products with a high VNF (e.g., vegetables, fruits) have a very low nitrogen content. As a result, the amount of nitrogen lost per the amount of nitrogen contained in those fruits and vegetables would be very low. An alternative metric that takes this into account is the total virtual nitrogen per total mass of food purchased. This is perhaps the most revealing of these metrics in terms of the intensity of nitrogen pollution for any institution's food purchasing patterns because it directly relates the institution total virtual nitrogen to the amount of food purchased. The average virtual nitrogen per food weight was $49 \mathrm{~kg}$ virtual $\mathrm{N}$ per $\mathrm{kg}$ food. Institutions with a higher ratfood purchased could lower their footprints by shifting away from purchasing animal products, especially beef, to purchasing more plant-based protein.

The institution $\mathrm{N}$ footprint of food production can also be broken down by the food categories used in the calculation. Figure 4 shows that for all institutions assessed, the nitrogen released from animal products is at least 57 percent of the total food production $\mathrm{N}$ footprint, and in most cases reaches over 80 percent of the total. These results indicate an opportunity for all institutions to reduce their $\mathrm{N}$ footprints by reducing the amount of animal products they purchase and serve.

The food consumption $\mathrm{N}$ footprint is the amount of nitrogen contained in food that is consumed, which ultimately ends up as sewage. Thus, ing of virtual nitrogen per mass of 
the resulting food consumption $\mathrm{N}$ footprint can be affected by the level of treatment at the local sewage treatment facility. Table 3 shows the sewage treatment nitrogen removal factor that was determined for local wastewater treatment plants for each institution. The nitrogen removal factor for sewage treatment is determined by the amount of denitrification of reactive nitrogen that is achieved as well as the amount of sewage sludge that is removed and repurposed.

The utilities $\mathrm{N}$ footprint can be normalized by total building space, which is measured as gross square footage (GSF) (Table 1, Figure 5). The utilities $\mathrm{N}$ footprints per GSF ranged from 0.9 to $14 \mathrm{~kg} \mathrm{~N}$ per GSF, with purchased electricity contributing over 86 percent to each normalized utilities $\mathrm{N}$ footprint. The utilities $\mathrm{N}$ footprint depends on building efficiency, climate, and fuel mix. Institutions that rely on purchased electricity in coal-dependent regions of the United States (UVA and EMU in Virginia, CSU in Colorado) show higher utility $\mathrm{N}$ footprints per GSF than institutions that are able to rely on energy sources with lower nitrogen emissions, such as natural gas, nuclear energy, and landfill biogas (Brown and UNH, both in New England). The trend $\left(\mathrm{R}^{2}=0.85\right.$, $p<0.01$ ) in comparing the utilities $\mathrm{N}$ footprint with campus GSF (Figure 6) suggests that GSF is a driving factor across institution $\mathrm{N}$ footprints. Differences in facility and building types also contribute to the utilities $\mathrm{N}$ footprint per GSF: for example, EMU has a lower utility $\mathrm{N}$ footprint per GSF than UVA, potentially because UVA has more research and medical facilities that are more energy intensive, and EMU has many highly efficient-rated buildings (LEED Gold).

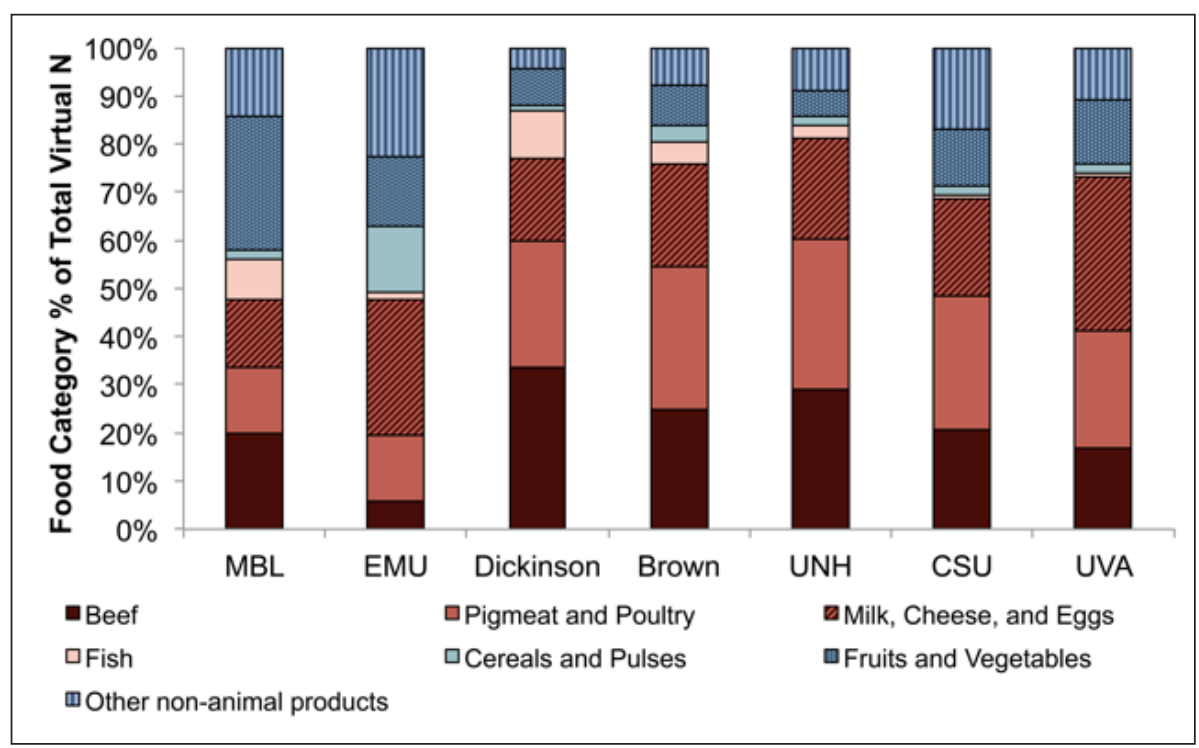

Figure 4. The percent contribution of each food category to an institution's virtual food $\mathrm{N}$ footprint (i.e., the $\mathrm{N}$ loss associated with food production). Results are shown for the seven institutions.

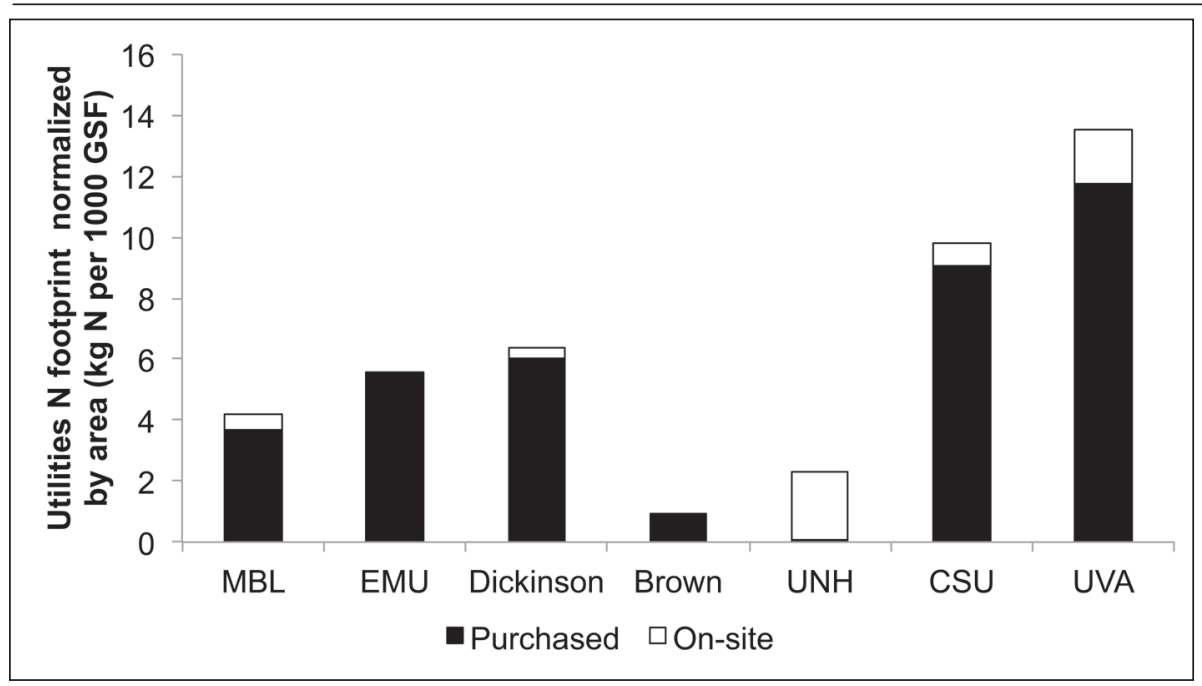

Figure 5. The $\mathrm{N}$ footprint of energy for electricity, heating, and cooling, from on- and off-site sources, normalized by gross square footage (GSF). Results are shown for the seven institutions.

Transportation nitrogen emissions can be compared on a per capita (FTE) basis (Figure 7). Commuting made up the majority $(72 \%)$ of each institution's per capita transit $\mathrm{N}$ footprint. The transportation $\mathrm{N}$ footprint per person for an institution depends on the distance traveled per commuter and commuting type-automobile commuting has a higher per capita $\mathrm{N}$ footprint than institutional or public transportation systems. Institutions have the option to include commercial flights associated with student and faculty travel for study abroad programs, athletics, and business, but these are not shown in the comparison because only four of the seven institutions have included this calculation. The per capita commercial air $\mathrm{N}$ footprint ranges from $0.2 \mathrm{~kg} \mathrm{~N}$ per capita at Eastern Mennonite University to $0.4 \mathrm{~kg} \mathrm{~N}$ per capita at Dickinson College. Both institutions included student travel for study abroad programs. 


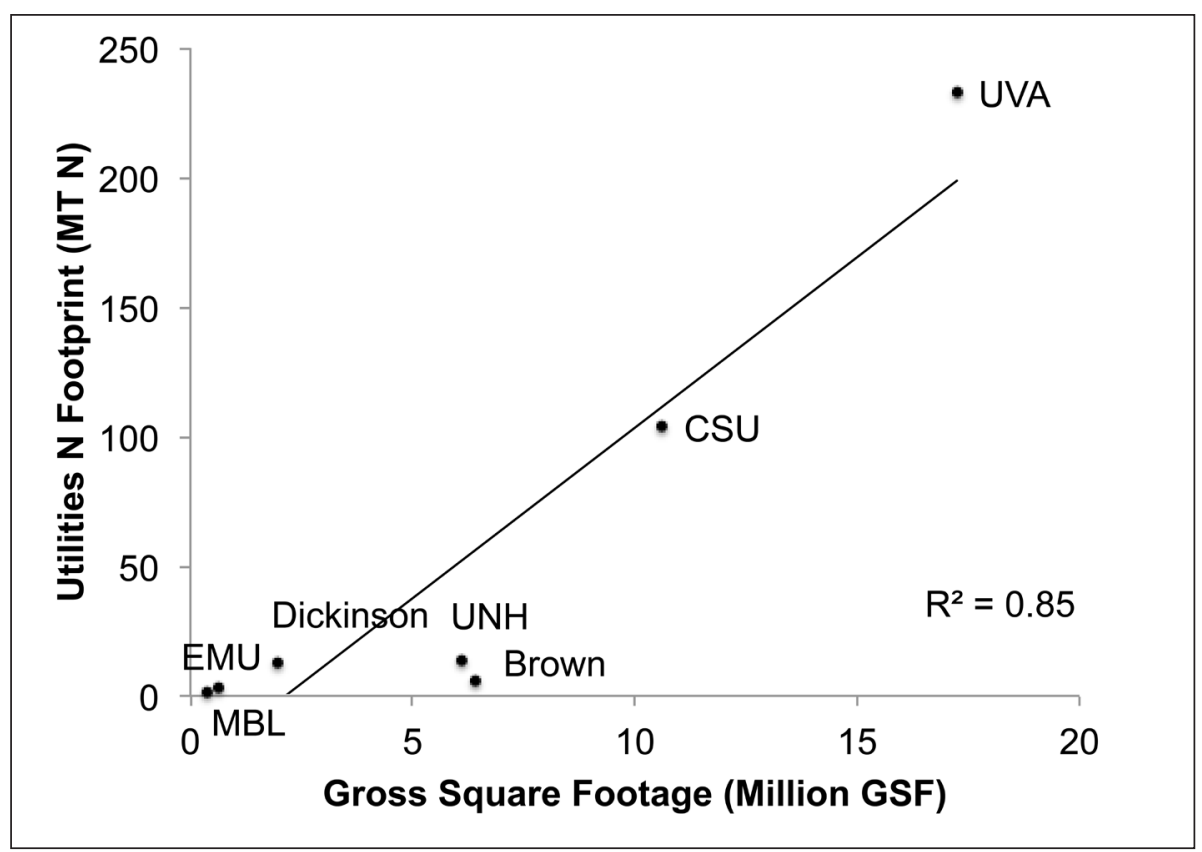

Figure 6. Linear regression between campus gross square footage (GSF) and the utilities $N$ footprint. A strong correlation ( $R^{2}=0.85$ ) was observed with a $p \leq 0.01$. Results are shown for the seven institutions.

\section{Discussion}

Comparison of the energy sectors of $\mathrm{N}$ footprints across institutions is fairly straightforward using both per capita and per building area metrics. In addition, these comparison metrics for energy footprints have already been established through carbon footprint research. These metrics do not predict the $\mathrm{N}$ footprint of energy consumption, which is driven by the emissions from fuel sources for both purchased electricity and on-site heating plants. In contrast to the energy sector comparisons, food sector comparisons are more difficult to interpret because few established metrics exist and food operations and tracking vary greatly between institutions. However, some understanding of how institution food $\mathrm{N}$ footprints compare can be derived from proportions of food types purchased. may be useful in future comparisons; a weighted campus-use metric for the percentage of total food consumed on-campus by the institution's population would better normalize across institutions than per capita metrics. Normalized metrics for institutions that classify the types of food purchased or meals served would improve food comparisons by providing a standard that applies across all institutions. When metrics are better normalized, it will be easier to compare institutions using $\mathrm{N}$ footprints.

The comparison metrics presented here overlap with standard sustainability reporting such as AASHE STARS. Metrics for utilities presented in this article relate to existing STARS 2.1 credits for greenhouse gas emissions (OP 1), outdoor air quality ( $O P$ 2), building energy consumption (OP 5), clean and renewable energy (OP 6), student commute modal split (OP 16), and employee commute modal split (OP 17). ${ }^{5}$ While the metrics presented in this article do not directly align with those reported in the Food and Beverage Purchasing section (OP 7 ), there is one STARS credit that is relevant to $\mathrm{N}$ footprint metrics and reporting: the percent of purchases that are conventional. ${ }^{6}$ Efforts to reduce conventional animal product purchasing may be attained by reducing animal purchases and therefore drive down the institution's food $\mathrm{N}$ footprint. (For a complete listing of STARS credits that align with $\mathrm{N}$ footprint reduction strategies, see Supplementary Material Table 1, which may be found online at www.liebertpub.com/sus.)

Scope 3 receives less attention than scopes 1 and 2 because only scopes 


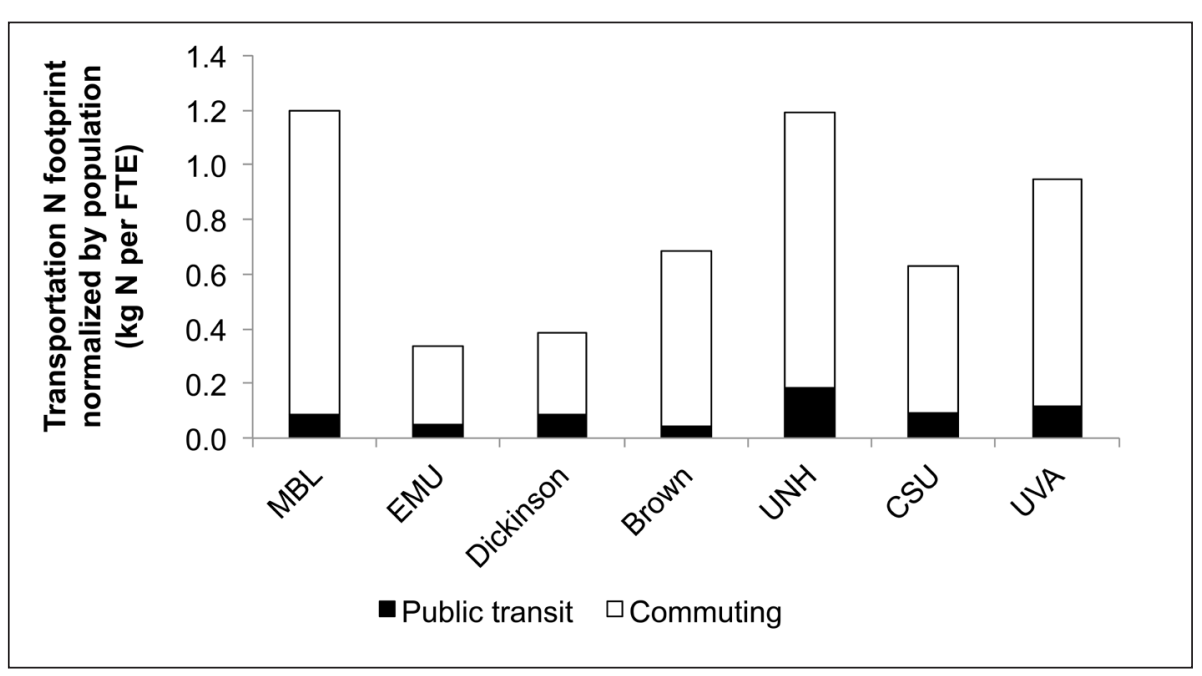

Figure 7. The transportation $N$ footprint includes public transit (i.e., institution-owned vehicles) and commuting; results are shown on a per capita basis. Results are shown for the seven institutions.

1 and 2 are required to complete a campus greenhouse gas inventory. In addition, scope 3 is often largely excluded from carbon footprints because the required data sets are often not available or are not tracked in a usable way. However, scope 3 sectors, especially food production, are very important for $\mathrm{N}$ footprints and other environmental impact assessments. In carbon footprints, the direct and industry energy emissions (scopes 1 and 2) are estimated at only about 26 percent of total supply chain emissions. ${ }^{3}$ For the seven $\mathrm{N}$ footprints assessed, scopes 1 and 2 make up 31 percent of the total footprint, on average. Supply-chain emissions, while more difficult to account for, should nevertheless be included in any complete accounting of $\mathrm{N}$ footprints and carbon footprints. ${ }^{7}$

A sustainable $\mathrm{N}$ footprint has not yet been defined for an institution or even an individual. What can institution comparisons tell us about assessing $\mathrm{N}$ footprints for sustainability? Comparisons reveal how different drivers affect $\mathrm{N}$ foot- prints-location, size, campus use, and system bounds - all of which contribute to the results of a Nitrogen Footprint Tool calculation and the management strategies that are possible for reducing an institution's impact. Additional information and normalized boundary setting could contribute to more meaningful comparisons that are able to inform institution sustainability assessments. Environmental damage costs of $\mathrm{N}$ footprints and side-byside comparisons with other footprint indicators, such as carbon,

A set of guidelines for a sustainable $\mathrm{N}$ footprint target is an important future research goal. These guidelines would help institutions determine their responsibility for reducing their $\mathrm{N}$ footprints and improve the ability to set meaningful reduction goals. ${ }^{9}$ Sustainable nitrogen footprints may be determined by an assessment of global thresholds for resource use and environmental pressures, ${ }^{10,11}$ but translating from global thresholds to institutional system boundaries is a large leap. will help inform this discussion. ${ }^{7,8}$
The geographic location of nitrogen emission sources plays a role in the sustainability of an institution $\mathrm{N}$ footprint because most negative effects of reactive nitrogen play out on regional scales. ${ }^{12}$ However, not all emission sources are easily traced: Sources for fossil fuel combustion for utilities and transportation are relatively transparent, but tracing trade through opaque food chains makes it difficult to link the location of food production emissions to the food purchased by the institution.

\section{Conclusion}

Nitrogen footprints for institutions are novel indicators of environmental impact because they show the contributions of both food and energy consumption and link to a broad range of environmental and human health impacts that are not addressed by other sustainability metrics. Results differ based on campus use and university operations, and comparison reveals the importance of common drivers and contributes to a broader discussion of the use of $\mathrm{N}$ footprints for institution sustainability. While more nuanced comparisons are needed to fully assess the sustainability and drivers of institutional $\mathrm{N}$ footprints, the work of the Nitrogen Footprint Tool Network has provided a solid basis of understanding.

\section{Acknowledgments}

The work of the Nitrogen Footprint Tool Network was supported by Cooperative Agreement No. 83563201 awarded by the U.S. Environmental Protection Agency.

\section{Author Disclosure Statement}

No competing financial interests exist. 


\section{References}

1. Castner EA, Leach AM, Leary $\mathrm{N}$, et al. The nitrogen footprint tool network: A multi-institution program to reduce nitrogen pollution. Sus J Record 2017;10:79-88.

2. University of New Hampshire Sustainability Institute and Sightlines. The State of Sustainability in Higher Education 2015: Emissions Metrics, Consumption Trends \& Strategies for Success. 2015. http://www.sightlines. com/insight/state-of-sustainabilityin-higher-ed-2015/ (last accessed 3/21/2017).

3. World Resources Institute and World Business Council for Sustainable Development. The Greenhouse Gas Protocol: A Corporate Accounting and Reporting Standard. World Resources Institute, Geneva, 2004.

4. Leach AM, Galloway JN, Bleeker A, et al. A nitrogen footprint model to help consumers understand their role in nitrogen losses to the environment. Environ Dev 1:40-66.
5. Matthews HS, Hendrickson CT, and Weber CL. The importance of carbon footprint estimation boundaries. Environ Sci Technol 2008;42:5839-5842.

6. Association for the Advancement of Sustainability in Higher Education Stars Technical Manual: Version 2.1. 2017. https://stars. aashe.org/pages/about/technical-manual.html (last accessed 3/21/2017).

7. Leach AM, Galloway JN, Castner EA, et al. An integrated tool for calculating and reducing institution carbon and nitrogen footprints. Sus J Record 2017;10:140-148.

8. Compton JE, Leach AM, Castner EA, et al. Assessing the social and environmental costs of institution nitrogen footprints. Sus J Record 2017;10:114-121.

9. Leach AM, Majidi AN, Galloway JN, et al. Toward institutional sustainability: A nitrogen footprint model for a university. Sus J Record 2013;6:211-219.
10. Hoekstra AY, and Wiedmann TO. Humanity's unsustainable environmental footprint. Science 2014;344:1114-1117.

11. Rockström, J, Steffen W, Noone $\mathrm{K}$, et al. Planetary boundaries: Exploring the safe operating space for humanity. Ecol Soc 2009;14(2):32. http://www.ecologyandsociety.org/ vol14/iss2/art32/ (last accessed 3/21/2017).

12. Galloway JN, Townsend AR, Erisman JW, et al. Transformation of the nitrogen cycle: Recent trends, questions, and potential solutions. Science 2008;320:889-892.

Address correspondence to:

Elizabeth A. Castner

Department of Environmental Sciences

University of Virginia

291 McCormick Road

Charlottesville, VA 22903

E-mail: eac6e@virginia.edu 